\title{
Effect of milk replacer feeding rate, age at weaning, and method of reducing milk replacer to weaning on digestion, performance, rumination, and activity in dairy calves to 4 months of age
}

\author{
T. S. Dennis, ${ }^{*}$ F. X. Suarez-Mena, ${ }^{*}$ T. M. Hill, ${ }^{* 1}$ J. D. Quigley, ${ }^{*}$ R. L. Schlotterbeck, ${ }^{*}$ and L. Hulbert† \\ *Nutrition and Research Center, Provimi, Brookville, OH 45309 \\ †Department of Animal Sciences and Industry, Kansas State University, Manhattan 66506
}

\begin{abstract}
The objectives of this study were to evaluate calf performance, diet digestibility, and rumination activity when feeding 4 milk replacer (MR) feeding programs. Male Holstein calves $(\mathrm{n}=96 ; 43 \pm 1.2 \mathrm{~kg}$ of body weight; 1 to $2 \mathrm{~d}$ of age) were housed in individual pens for $56 \mathrm{~d}$. Calves were fed a common MR [25\% crude protein (CP), $17 \%$ fat, dry matter (DM) basis]. Feeding programs were (1) $0.66 \mathrm{~kg}$ of DM/d of MR and weaning at $42 \mathrm{~d}$ (MOD6); (2) up to $1.09 \mathrm{~kg}$ of $\mathrm{DM} / \mathrm{d}$ of $\mathrm{MR}$ weaned at $42 \mathrm{~d}$ (HIGH6); (3) up to $1.09 \mathrm{~kg}$ of DM/d of MR weaned at $53 \mathrm{~d}$ (HIGH8); and (4) up to $1.09 \mathrm{~kg}$ of DM/d of MR and gradually weaned from d 35 to 53 (GRAD8). Calves were fed a textured starter containing whole grains with $20 \% \mathrm{CP}$ and $37 \%$ starch (DM basis). From 38 to $56 \mathrm{~d}$ of age, 4 calves/treatment had ear tag accelerometers fitted to provide measurements for eating, rumination, and activity. Calves were moved into groups by treatment ( 4 calves/pen) at $56 \mathrm{~d}$ and fed the same starter blended with $5 \%$ hay. Fecal samples were collected for individual calves between d 31 to 35 , 45 to49 (MOD6 and HIGH6 only), and 56 to 60 from 5 calves/treatment. Fecal samples were collected by pen from d 80 to 84 and 108 to 112. Data were analyzed as a randomized complete block design with repeated measures when appropriate. Preplanned contrasts of MOD6 versus others, HIGH6 versus HIGH8, and HIGH8 versus GRAD8 were used to separate the means. Calves fed MOD6 were $3.4 \mathrm{~kg}$ lighter at $56 \mathrm{~d}$ than calves fed other treatments. Starter intake was greatest for MOD6 compared with other treatments $(0.78$ vs. $0.43 \mathrm{~kg} / \mathrm{d}$ ) from 0 to $56 \mathrm{~d}$. Hip width and body condition score change from 0 to $56 \mathrm{~d}$ were similar among treatments. Average time ruminating, eating, and activity did not differ among treatments. Total-tract digestibility of
\end{abstract}

Received August 15, 2017.

Accepted September 14, 2017.

${ }^{1}$ Corresponding author: mhill@provimi-na.com
DM, OM, CP, and fat were least for calves fed MOD6 versus other treatments on $\mathrm{d} 35$, whereas NDF and starch digestibility were greatest for MOD6 at d 35. Digestibility of ADF and NDF were also greatest for MOD6 at d 49 (compared with HIGH6 only) and 60. From d 56 to 112, calves previously fed MOD6 had greater ADG versus other treatments. At $84 \mathrm{~d}$, DM, $\mathrm{OM}, \mathrm{CP}, \mathrm{NDF}, \mathrm{ADF}$, and fat digestibility were greatest for calves fed MOD6 versus others. Calves fed HIGH6 and GRAD8 had greater digestibility of NDF and ADF compared with HIGH8 at 84 d. At 112 d, digestibility was similar among treatments. Calves were not different in BW and hip width at $112 \mathrm{~d}$, with growth driven by less digestion of DM and fiber around and after weaning for calves fed $>0.66 \mathrm{~kg}$ of MR. Gradual weaning did improve postweaning digestion.

Key words: calf, weaning age, digestibility, activity

\section{INTRODUCTION}

A major difficultly in feeding large amounts milk or milk replacer (MR) is that the greater preweaning ADG and weaning BW typically reported is lost by approximately 4 mo of age compared with moderate MR programs feeding approximately $0.66 \mathrm{~kg}$ of DM (Hill et al., 2007, 2016a,b). Calves fed MR with computerized automatic feeders that allotted increasing amounts of MR from 6 to $12 \mathrm{~L} / \mathrm{d}$ had starter intake in the first 6 wk of age that averaged 0 to $0.1 \mathrm{~kg} / \mathrm{d}$ on the $8-, 10-$, and $12-\mathrm{L}$ allotments, whereas intake was $0.3 \mathrm{~kg} / \mathrm{d}$ with the 6-L/d treatment (Rosenberger et al., 2017). Similarly, low early solid feed intakes were reported among calves on non-computer-fed ad libitum systems (Nocek and Braund, 1986; Hill et al., 2013) and calves hand-fed $\mathrm{MR}$ at more than $0.7 \mathrm{~kg}$ of DM/d (Cowles et al., 2006; Hill et al., 2007, 2010). Although the transition period of reducing milk or MR is affected by MR feeding rate (more MR results in less starter intake; Rosenberger et al., 2017), postweaning starter intakes are not typically affected by preweaning feeding MR rates (Hill et al., 2007, 2013; Osorio et al., 2012). 
The results of MR feeding rate on postweaning ADG has varied among research groups. Some researchers report no effect (Miller-Cushon et al., 2013; Rosenberger et al., 2017), whereas others report a reduction in ADG (Cowles et al., 2006; Hill et al., 2007, 2010). However, a common result of increased MR feeding rate is reduced postweaning structural growth (Hill et al., 2016a,b). Several researchers identified that feeding high amounts of MR reduces post-weaning starter digestion (Terre et al. 2007a,b; Hill et al., 2010). This reduction in postweaning digestion can last $4 \mathrm{wk}$ or more (Hill et al., 2016b); however, few researchers measured effects of MR feeding rates beyond 2 wk postweaning. Therefore, the reported reductions in ADG and structural growth of calves fed over $0.7 \mathrm{~kg}$ of DM from MR after weaning may be due to reduced starter digestion (Terre et al. 2007a,b; Hill et al., 2010, 2016b), rather than starter intake (Osorio et al., 2012; Hill et al., 2016a,b).

One possible solution to this challenge may be to gradually reduce $\mathrm{MR}$ allowance over several days to wean calves fed high MR rates. Although several researchers tested gradual weaning in high MR-fed calves, postweaning diet digestibility was not reported (Hill et al., 2007, 2012; Sweeney et al., 2010). However, Hill et al. (2016b) reported increased postweaning digestion and growth after gradually weaning high MR-fed calves (stepped-down from $1.1 \mathrm{~kg} / \mathrm{d}$ of $\mathrm{MR}$ to $0.66 \mathrm{~kg} / \mathrm{d}$ for a 3-wk period before complete MR weaning) compared with high MR-fed calves stepped down over a 1-wk period. Extending the time preweaning when feeding a high rate of MR has been suggested to assist with the success of the programs when measuring $\mathrm{BW}$ gain to 10 (Eckert et al., 2015) and 13 wk (Meale et al., 2015) of age. Eckert et al. (2015) reported 8.9-kg heavier calves at 10 wk of age with 8 versus 6 wk of weaning, and Meale et al. (2015) reported 5.2-kg heavier calves at 13 wk of age with 12 versus 8 wk of weaning. However, neither of those studies reported structural growth measurements and postweaning measurements were assessed over a short length of time.

A challenge when interpreting milk and MR feeding rate research is many calf researchers report a short time length for postweaning measures: many report only a week to less than a month of postweaning data (Cowles et al., 2006; Miller-Cushon et al., 2013; Rosenberger et al., 2017). Another challenge is that structural growth is not routinely reported (Miller-Cushon et al., 2013; Rosenberger et al., 2017). Structural growth measurements may be more accurate measures of growing calves than BW and ADG because gastrointestinal tract (GIT) fill may influence these measurements, especially during the immediate postweaning period when calves may consume more feed than can be efficiently used within the GIT. For example, when a calf has little starter intake preweaning but a rapid increase in starter intake over a 1- or 2-wk period during and after weaning (Rosenberger et al., 2017), the GIT fills with digesta and passage rate may slow down; therefore, BW may not represent structural growth (i.e., muscle, bone, GIT tissue, and adipose; Khan et al., 2011).

Considering the issue of losing early growth from feeding more milk or MR during the postweaning phase, our objectives were to measure the growth and digestion pre- and in an extended postweaning period from feeding a moderate $(0.66 \mathrm{~kg})$ and high (up to 1.1 $\mathrm{kg}$ ) amount of MR, 2 weaning times (42 and $54 \mathrm{~d}$ ), with abrupt $(7 \mathrm{~d})$ and gradual $(14 \mathrm{~d})$ weaning. We hypothesized that a high feeding rate of MR with later and gradual weaning would support more growth and similar post-weaning digestibility as calves fed a moderate amount $(0.66 \mathrm{~kg}$ of $\mathrm{DM})$ of MR.

\section{MATERIALS AND METHODS}

\section{Animals, Facilities, and Treatments}

All animals were cared for as described in the Guide for the Care and Use of Agricultural Animals in Research and Teaching (FASS, 2010) and under approval of the institutional animal care and use committee. Male Holstein calves ( 3 to $4 \mathrm{~d}$ of age) were received at the Nurture Research Center nursery in southwest Ohio (New Paris) from 1 farm after a 3.5-h transit. The trial used 2 blocks of 48 calves received $70 \mathrm{~d}$ apart. The nursery included individual pens for calves in a barn with curtain sides, natural ventilation, and no added heat. Calf pens were bedded with long wheat straw. The day after arrival, at approximately noon, the calves were weighed (d 0; $43 \pm 1.2 \mathrm{~kg}$ of initial $\mathrm{BW}$, mean $\pm \mathrm{SE}$ ). At this time, blood was sampled intravenously, serum was separated by centrifugation at $3,000 \times g(\mathrm{VWR}$, Batavia, IL) at $20^{\circ} \mathrm{C}$ for 15 min, and serum protein concentration was estimated using an optical refractometer (ATAGO U.S.A. Inc., Bellevue, WA). All calves were initially fed $0.66 \mathrm{~kg}$ of DM from MR for first p.m. and following a.m. feeding, then randomly assigned to 1 of 4 feeding programs: (1) $0.66 \mathrm{~kg}$ of DM/d for first $39 \mathrm{~d}$ and $0.33 \mathrm{~kg}$ for $3 \mathrm{~d}$ fed in the a.m. feeding only (MOD6); (2) $0.87 \mathrm{~kg}$ of $\mathrm{DM} / \mathrm{d}$ for $4 \mathrm{~d}, 1.09 \mathrm{~kg}$ for $31 \mathrm{~d}$, and 0.54 $\mathrm{kg}$ for $7 \mathrm{~d}$ in the a.m. feeding (HIGH6); 3) $0.87 \mathrm{~kg}$ of $\mathrm{DM} / \mathrm{d}$ for $4 \mathrm{~d}, 1.09 \mathrm{~kg}$ for $42 \mathrm{~d}$, and $0.54 \mathrm{~kg}$ for $7 \mathrm{~d}$ in the a.m. feeding (HIGH8); and (4) $0.87 \mathrm{~kg}$ of DM/d for $4 \mathrm{~d}, 1.09 \mathrm{~kg}$ for $35 \mathrm{~d}, 0.87 \mathrm{~kg}$ for $4 \mathrm{~d}, 0.66 \mathrm{~kg}$ for 4 $\mathrm{d}, 0.44 \mathrm{~kg}$ for $3 \mathrm{~d}$, and $0.22 \mathrm{~kg}$ for $3 \mathrm{~d}$ in the a.m. feeding (GRAD8). Calves were fed a common MR $(25 \%$ CP, $17 \%$ fat DM basis; $14 \%$ solids; Table 1) in equal meals at 0600 and $1530 \mathrm{~h}$. This MR was formulated with added synthetic AA (Hill et al., 2008) and fatty 
acids (Hill et al., 2011). Rejected MR was weighed back after each feeding. A whole-grain, textured calf starter (20\% CP, $37 \%$ starch; specific fatty acids added as in Hill et al., 2011; Table 1) and water were fed for ad libitum intake during the nursery trial. Every other bag of MR and calf starter was sampled and composited for nutrient analysis. Feces were scored daily using a 1 to 5 scale, with 1 being normal and 5 being watery (modified from Kertz and Chester-Jones, 2004). Antibiotic medical treatments were recorded daily and were based on a binomial scoring system of lethargy, coughing, nasal discharges, or rectal temperatures $>39.4^{\circ} \mathrm{C}$. Calves with fecal scores $>2$ received oral electrolytes, but these were not counted as medical treatments. Calves were weighed weekly and BCS (1 being thin and 5 being obese; modified from Wildman et al., 1982) and hip widths were measured on $\mathrm{d} 0$ and every 2 wk thereafter.

On d 56, calves from the nursery trial were grouped by preweaning treatment and moved to pens (4 calves/ pen within treatment) until $112 \mathrm{~d}$ of age. The pens had $6.5 \mathrm{~m}^{2}$ of outside pen space and $1.35 \mathrm{~m}^{2}$ of inside pen space per calf and was bedded with wheat straw. Calf starter used in the nursery trial was blended with $5 \%$ chopped grass hay (approximately $2.5 \mathrm{~cm}$ long) on an as-fed basis and fed for ad libitum intake with free-choice access to water. Grower feed refusals were weighed daily to determine DMI. Every other bag of starter and every bale of hay was sampled and composited for nutrient analysis. Calf BW, hip width, and BCS were determined on d 56, 84, and 112 .

During the first block, the average ambient temperature was $21^{\circ} \mathrm{C}$ (range of $0-33^{\circ} \mathrm{C}$ ) and the average relative humidity was $77 \%$ (range of $17-100 \%$ ). During the second block, the average ambient temperature was $12^{\circ} \mathrm{C}$ (range of -16 to $32^{\circ} \mathrm{C}$ ) and the average relative humidity was $82 \%$ (range of $22-100 \%$ ).

\section{Digestibility Pre- and Postweaning}

In the nursery trial, 5 calves/treatment in 1 block of calves were randomly selected for use in digestibility analysis. During d 31 to 35 (denoted as d 35), 45 to 49 (denoted as d 49; MOD6 and HIGH6 only), and 56 to 60 (denoted as d 60), fecal grab samples were palpated rectally from each calf and composited by calf for use to estimate total-tract diet digestibility, as described by Hill et al. (2016a). Chromic oxide was added to MR as described by Hill et al. (2016a) for use as an external marker for samples collected for d 35. Acid-insoluble ash was used as an internal marker for samples collected for d 49 and 60. Calves used for digestibility estimates remained in the nursery 4 extra days to facilitate fecal sampling. During d 80 to 84 (denoted as d 84) and 108 to 112 (denoted as d 112), fecal samples
Table 1. Analyses of feeds used in current trials

\begin{tabular}{lccrrr} 
& \multicolumn{2}{c}{ Nursery } & & \multicolumn{2}{c}{ Grower } \\
\cline { 2 - 3 } \cline { 5 - 6 } Nutrient $^{1}$ & MR $^{2}$ & Starter $^{3}$ & & Starter & Hay \\
\hline DM, \% as fed & 96.6 & 86.9 & & 87.5 & 92.8 \\
CP & 24.9 & 20.8 & & 20.8 & 6.9 \\
ADF & - & 6.6 & & 6.7 & 42.2 \\
NDF & - & 15.9 & & 15.3 & 63.5 \\
Sugar & - & 6.2 & & 6.1 & 4.3 \\
Starch & - & 37.2 & & 37.3 & 0.7 \\
Fat & 17.9 & 3.7 & & 3.6 & 1.5 \\
Ash & 5.6 & 5.9 & & 6.3 & 5.8 \\
ME, ${ }^{4}$ Mcal/kg & 4.6 & 3.1 & & 3.1 & 2.2 \\
\hline
\end{tabular}

${ }^{1}$ Percent of DM, unless otherwise stated.

${ }^{2}$ Milk replacer manufactured from whey, whey protein concentrate, and animal fat.

${ }^{3} 37 \%$ whole corn, $35 \%$ protein/mineral pellet, $25 \%$ whole oats, and $3 \%$ liquid molasses.

${ }^{4}$ Calculated using NRC (2001) equations.

were taken from each pen floor, with care not to sample floor materials, and composited by pen for use to estimate diet digestibility using acid-insoluble ash. Feed was offered daily for minimal refusals (averaging 2.4\% of offered), and refusals during the digestion periods were saved daily by pen, composited, and sampled for analysis. The nursery and group pens were bedded with long wheat straw and straw consumption by calves was possible (Hill et al., 2010, 2016a,b). This was accounted for by not adding new bedding $3 \mathrm{~d}$ before and during fecal collection periods to minimize the chance of straw intake during the week of digestibility measurements. Mathematically, unaccounted for consumption of straw could have reduced estimates of digestibility.

\section{Rumination Behavior and Activity}

At 4 wk of age, 4 of the 5 calves in 1 block of calves selected for digestibility estimates were randomly assigned to have an ear tag placed in its ear that encased a 3-dimensional accelerometer. The eartags (CowManager SensOor, Agis, Harmelen, the Netherlands) were attached to radio-frequency identification female buttons using a long male pin supplied by the supplier company to fit through the radio-frequency identification button. Application of the SensOors to the ear and management of the calves are described in Hill et al. (2017). Data from the ear tags were processed using commercially available, proprietary software algorithms (CowManager; https://www.cowmanager.com/en-us) to provide hourly measurements recorded each minute for eating (including MR plus starter), ruminating, and activity, all mutually exclusive times. The sensors were validated (Hill et al., 2017) using live observation with instantaneous recording and were found to be accurate 
at measuring 4- to 6-wk-old calves' rumination $\left(\mathrm{R}^{2}=\right.$ $0.91)$, eating $\left(\mathrm{R}^{2}=0.75\right)$, and activity times $\left(\mathrm{R}^{2}=\right.$ 0.97). Eating, rumination, and activity measurements $(\mathrm{min} / \mathrm{h})$ from d 38 to 56 were compared among treatments.

\section{Feed and Digestibility Analyses}

Composites of feeds, refusals, and feces were analyzed (AOAC International, 2000) for DM (oven method 930.15), ash (oven method 942.05), CP (Kjeldahl method 988.05), fat (alkaline treatment with RoeseGottlieb method 932.06 for MR; diethyl ether extraction method 2003.05 for starters and hay), NDF with ash by the procedure of Van Soest et al. (1991) without sodium sulfite or $\alpha$-amylase, ADF with ash (Robertson and Van Soest, 1981), starch ( $\alpha$-amylase method; Hall, 2009), sugar (colorimetric method; Dubois et al., 1956), chromic oxide (in MR only; Bouchard et al., 1973), and acid-insoluble ash (Van Keulen and Young, 1977).

\section{Statistical Analyses}

In the nursery trial, intake and BW data were grouped by week, whereas hip width and BCS change were grouped by 14-d periods. In the grower trial, intake, BW, hip width, and BCS data were grouped by 28-d periods. Data were analyzed as a randomized complete block design with repeated measures when applicable by PROC MIXED in SAS (version 8, SAS Institute Inc., Cary, NC). Block was starting date of calves (2 blocks). Digestibility data were analyzed by individual collection periods independently and combined within trial (d 35, 49, and 60 combined in nursery; d 84 and 112 combined in grower) with repeated measurements. Behavior data $(\mathrm{min} / \mathrm{h})$ were analyzed for 1 - and $24-\mathrm{h}$ periods. An autoregressive type 1 covariance matrix was employed as determined using Akaike's information criteria. Exceptions were BCS, abnormal fecal score days, and medical days, which were summed over the nursery trial and analyzed using Kruskal-Wallis test with PROC NPAR1WAY in SAS. Calf was the experimental unit in the nursery trial and pen (4 calves/pen) was the experimental unit in the grower trial. Preplanned contrast statements of MOD6 versus others, HIGH6 versus HIGH8, and HIGH8 versus GRAD8 were used to separate the means. Significance was determined at $P \leq 0.05$; trends were considered at $0.10 \geq P>0.05$.

\section{RESULTS}

In the nursery trial, initial calf measurements did not differ among treatments (Table 2). No MR fed was rejected. Intake of MR DM was 27.6 kg for MOD6,
$56.9 \mathrm{~kg}$ for HIGH6, $58.3 \mathrm{~kg}$ for HIGH8, and $54.6 \mathrm{~kg}$ for GRAD8 per calf during the nursery trial. Starter DMI was greater $(P<0.001)$ for calves fed MOD6 versus others and for HIGH6 versus HIGH8, and we noted a day and day $\times$ treatment response $(P<0.01$; Figure 1). Starter intake was greater $(P<0.05)$ for MOD6 versus others for wh 4 to 8 and greater $(P<$ $0.05)$ for HIGH6 versus HIGH8 for wk 6 to 8 . Total $\mathrm{ME}$ and $\mathrm{CP}$ intake (MR plus starter) was less $(P<$ $0.01)$ for MOD6 versus others and there was a day and day $\times$ treatment response $(P<0.01)$. Calf ADG and feed efficiency (ADG/DMI) were less $(P<0.05)$ for calves fed MOD6 versus others and for HIGH6 versus HIGH8. A treatment $\times$ time interaction was observed for calf BW and hip width $(P<0.05$; Figure 2). Calf BW gain was less $(P<0.01)$ for MOD6 versus other treatments for wk 2 to 8 . Calf hip width change was less $(P<0.05)$ for MOD6 versus other treatments for wk 4 . Final BW was less $(P<0.01)$ for calves fed MOD6 versus others. Calf ADG/DMI was less $(P<$ 0.05) for calves fed MOD6 versus others and HIGH8 versus GRAD8; however, ADG/ME intake and ADG/ $\mathrm{CP}$ intake did not differ among treatments. Medical days were less $(P<0.01)$ for calves fed MOD6 versus others, for HIGH6 versus HIGH8, and GRAD8 versus HIGH8. Medical treatments were primarily related to coughing and nasal discharges. Final BCS was less $(P<$ 0.05) for calves fed MOD6 versus others and for HIGH6 versus HIGH8. During the grower trial, ADG, ADG/ DMI, and hip width change were greater $(P<0.05)$ for calves fed MOD6 vs. others (Table 3). Final BCS was less $(P<0.05)$ for calves fed MOD6 versus others. Other performance measurements did not differ.

Over the $112 \mathrm{~d}$ of both the nursery and grower trials, total DMI were $243 \mathrm{~kg}$ for MOD6, $263 \mathrm{~kg}$ for HIGH6, $261 \mathrm{~kg}$ for HIGH8, and $252 \mathrm{~kg}$ for GRAD8. Total BW gains were $95 \mathrm{~kg}$ for MOD6, $92 \mathrm{~kg}$ for HIGH6, $94 \mathrm{~kg}$ for HIGH8, and $97 \mathrm{~kg}$ for GRAD8. Overall ADG/DMI $(\mathrm{kg} / \mathrm{kg})$ were 0.39 for MOD6, $0.35 \mathrm{~kg}$ for HIGH6, 0.36 $\mathrm{kg}$ for HIGH8, and $0.38 \mathrm{~kg}$ for GRAD8. Total hip width change were $9.3 \mathrm{~cm}$ for MOD6, $8.4 \mathrm{~cm}$ for HIGH6, 8.7 $\mathrm{cm}$ for HIGH8, and $9.1 \mathrm{~cm}$ for GRAD8. We did not evaluate these statistically, as the experimental units differed between the nursery (1 calf) and grower (pen of 4 calves) trials.

Digestibility measurements for d 35, 49, and 60 are shown in Table 4. Digestibility of DM, OM, CP, and fat were less $(P<0.05)$ for calves fed MOD6 versus others on d 35. Digestibility of ADF, NDF, and starch were greater $(P<0.05)$ for MOD6 versus others on d 35. Additionally, digestibility $\mathrm{ADF}$ and NDF were greater $(P$ $<0.05$ ) for MOD6 versus others on d 49 and 60. Starch digestibility was greater $(P<0.05)$ for HIGH8 versus GRAD8 and CP digestibility tended to be greater for 
Table 2. Performance of calves fed 4 milk replacer (MR) programs $^{1}$ from d 0 to 56

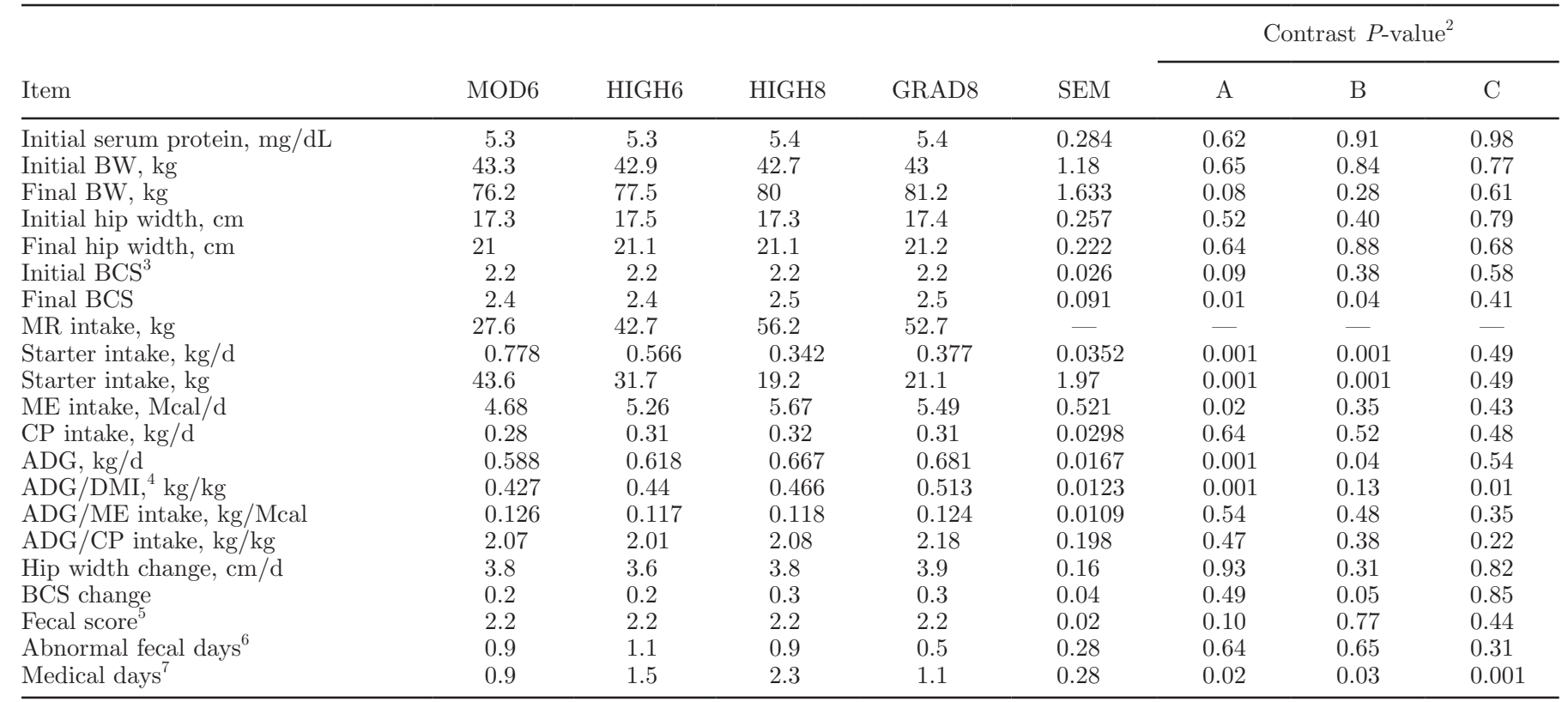

${ }^{1} \mathrm{MOD} 6=0.66 \mathrm{~kg}$ of MR DM from d 0 to $39,0.33 \mathrm{~kg}$ from d 40 to $42 ; \mathrm{HIGH} 6=0.87 \mathrm{~kg}$ from d 0 to $4,1.09 \mathrm{~kg}$ from d 5 to $35,0.54 \mathrm{~kg}$ from d 36 to $42 ; \mathrm{HIGH} 8=0.87 \mathrm{~kg}$ from d 0 to $4,1.09 \mathrm{~kg}$ from d 5 to $45,0.54 \mathrm{~kg}$ from d 46 to $53 ;$ GRAD $8=0.87 \mathrm{~kg}$ for $4 \mathrm{~d}, 1.09 \mathrm{~kg}$ from d 5 to 39 , $0.87 \mathrm{~kg}$ from d 40 to $43,0.66 \mathrm{~kg}$ from d 44 to $47,0.44 \mathrm{~kg}$ from d 48 to $50,0.22 \mathrm{~kg}$ from d 51 to 53.

${ }^{2}$ Preplanned contrasts as follows: A = MOD6 vs. (HIGH6 + HIGH8 + GRAD8)/3; B = HIGH6 vs. HIGH8; C = HIGH8 vs. GRAD8.

${ }^{3} 1$ to 5 point scale (modified from Wildman et al., 1982).

${ }^{4}$ Total BW gain/(MR + starter intake).

${ }^{5} 1$ to 5 point scale with: $1=$ normal, thick; $2=$ normal, less thick; $3=$ abnormal, like pancake batter; $4=$ abnormal, watery with color; $5=$ abnormal, watery with little to no color.

${ }^{6}$ Days with fecal scores $>2$ (analyzed using Kruskal-Wallis test).

${ }^{7}$ Days with antibiotic treatments for fever and lethargy, not including electrolytes (analyzed using Kruskal-Wallis test).

GRAD8 versus HIGH8 on d 60. Digestibility of ADF (Figure 3) and NDF increased $(P<0.05)$ in a similar manner with day during the nursery trial. We noted a similar treatment $\times$ day interaction for digestibility of OM (Figure 4) and DM $(P<0.01)$. Digestibility of DM and $\mathrm{OM}$ was less $(P<0.05)$ for MOD6 versus other treatments on d 35, but greater $(P<0.05)$ than others on d 60. Digestibility measurements for d 84 and 112 are shown in Table 5. At d 84, digestibility of DM, OM, $\mathrm{ADF}, \mathrm{NDF}, \mathrm{CP}$, and fat were greater $(P<0.05)$ for calves fed MOD6 versus others. At d 112, starch digestibility was less $(P<0.05)$ for MOD6 versus others; also, starch digestibility was less $(P<0.05)$ for HIGH8 versus GRAD8. Figures 1 and 2 show the digestibility of $\mathrm{OM}$ and $\mathrm{ADF}$ across the nursery and grower periods by treatment.

Time ruminating, eating, and active did not differ among treatments from d 38 to 56 , which is shown with treatments combined by hour of the day in Figure 5 . Behavior changes to removing MR (weaning) were minor. When comparing the hour during and after feeding MR (1500-1700 h) for the last time to feed MR to the next day when MR was not fed, the time ruminating, eating, and active for reducing MR to facilitate weaning did not differ except for HIGH6 and HIGH8. When the MR fed in the p.m. was removed from calves fed MOD6 on $d$ 36, their time not active decreased from 22 to $13 \pm 2.5 \min (P=0.03)$. When the MR fed in the p.m. was removed from calves fed HIGH8 on d 47 , their time not active decreased from 25 to $14 \pm 2.8 \mathrm{~min}$ $(P=0.04)$ compared with the day before. We observed no reductions or other changes for the other treatments when MR rates were changed.

\section{DISCUSSION}

The effects of increasing MR fed increased preweaning ADG and reduced preweaning starter intake, whereas reducing ADG and hip width change from 56 to 112 d was a similar result in previous research (Hill et al., 2013, 2016a,b). Additionally, similar 112-d BW and hip widths among treatments but greater BCS on calves fed higher MR rates were also similar to results observed in previous research (Hill et al., 2013, 2016a,b). Fiber digestibility at d 35 was low for all groups and increased on d 49 and 60 , similar to digestibility esti- 


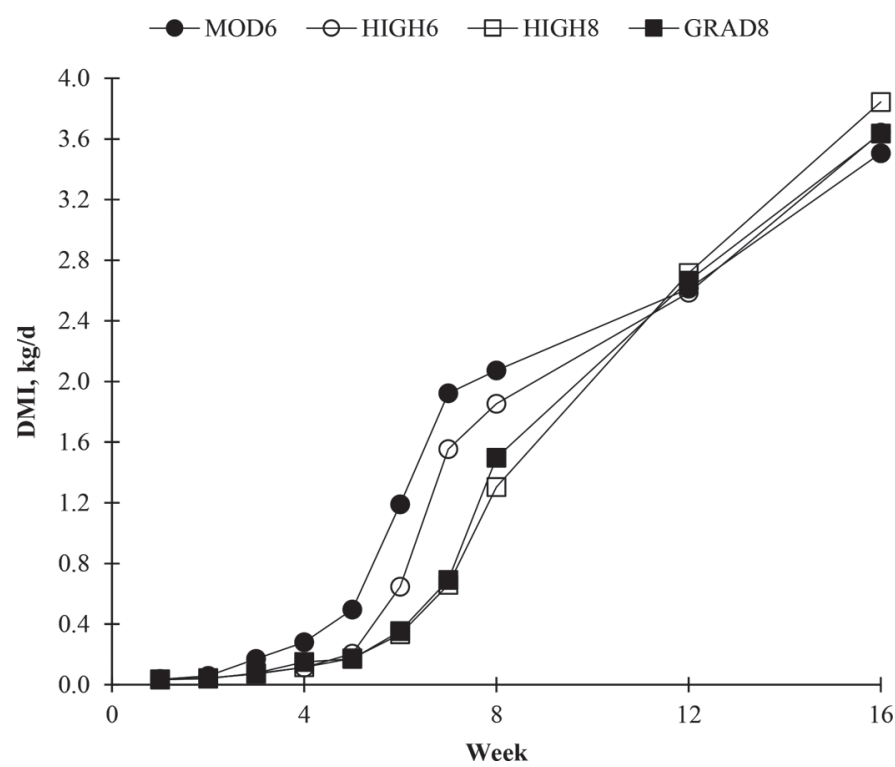

Figure 1. Intake of DM from starter during the nursery trial (0-8 wk) and starter with 5\% hay during the grower (8-16 wk) trial for calves fed 4 milk replacer programs. Intake increased with day $(P<$ $0.01)$ and we found a treatment $\times$ day interaction $(P<0.01)$. MOD6 was greater than others at wk 4 to $8(P<0.05)$; HIGH6 $>$ HIGH8 at wk 6 to $8(P<0.05)$. Overall SEM $\leq 0.1 \mathrm{~kg}$. Feeding programs were MOD6 $=0.66 \mathrm{~kg}$ of milk replacer DM from d 0 to $39,0.33 \mathrm{~kg}$ from d 40 to $42 ; \mathrm{HIGH} 6=0.87 \mathrm{~kg}$ from d 0 to $4,1.09 \mathrm{~kg}$ from d 5 to $35,0.54$ $\mathrm{kg}$ from d 36 to $42 ; \mathrm{HIGH} 8=0.87 \mathrm{~kg}$ from d 0 to $4,1.09 \mathrm{~kg}$ from d 5 to $45,0.54 \mathrm{~kg}$ from d 46 to 53 ; GRAD $8=0.87 \mathrm{~kg}$ for $4 \mathrm{~d}, 1.09 \mathrm{~kg}$ from d 5 to $39,0.87 \mathrm{~kg}$ from d 40 to $43,0.66 \mathrm{~kg}$ from d 44 to $47,0.44 \mathrm{~kg}$ from d 48 to $50,0.22 \mathrm{~kg}$ from d 51 to 53.

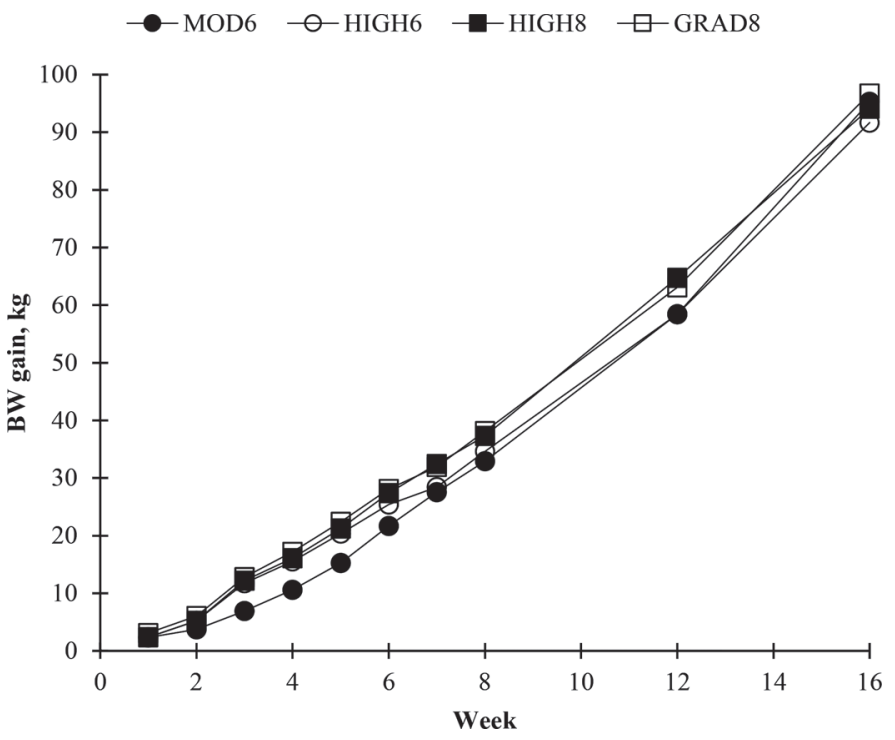

Figure 2. Body weight gain during the nursery $(0-8 \mathrm{wk})$ and grower trials $(8-16$ wk) for calves fed 4 milk replacer programs. Gain increased with day $(P<0.01)$ and we found a treatment $\times$ day interaction $(P<0.01)$. MOD6 was greater than others at wk 2 to $8(P<$ $0.05)$; HIGH6 $<$ HIGH8 at wk 7 to $12(P<0.05)$. Overall SEM $\leq 1 \mathrm{~kg}$. Feeding programs were MOD6 $=0.66 \mathrm{~kg}$ of milk replacer DM from d 0 to $39,0.33 \mathrm{~kg}$ from d 40 to $42 ; \mathrm{HIGH} 6=0.87 \mathrm{~kg}$ from d 0 to $4,1.09 \mathrm{~kg}$ from d 5 to $35,0.54 \mathrm{~kg}$ from d 36 to $42 ; \mathrm{HIGH} 8=0.87 \mathrm{~kg}$ from d 0 to $4,1.09 \mathrm{~kg}$ from d 5 to $45,0.54 \mathrm{~kg}$ from d 46 to $53 ;$ GRAD $8=0.87 \mathrm{~kg}$ for $4 \mathrm{~d}, 1.09 \mathrm{~kg}$ from d 5 to $39,0.87 \mathrm{~kg}$ from d 40 to $43,0.66 \mathrm{~kg}$ from d 44 to $47,0.44 \mathrm{~kg}$ from d 48 to $50,0.22 \mathrm{~kg}$ from d 51 to 53 .

Table 3. Performance of calves from 56 to $112 \mathrm{~d}$ of age as influenced by the 4 milk replacer programs ${ }^{1}$ fed

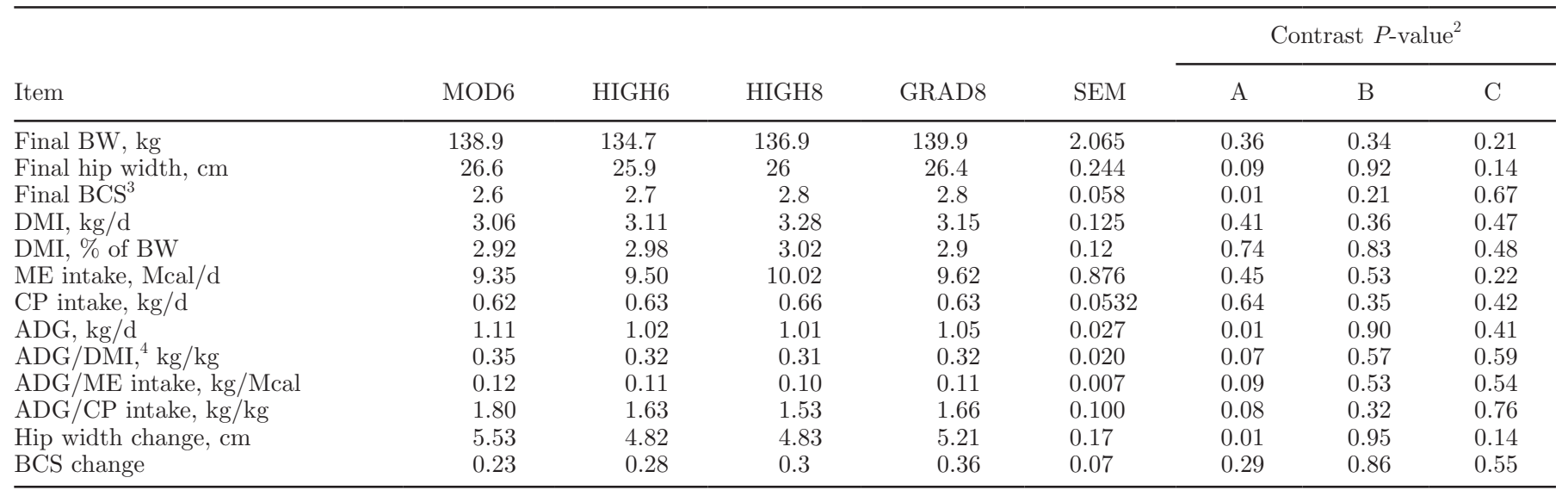

${ }^{1}$ MOD6 $=0.66 \mathrm{~kg}$ of milk replacer DM from d 0 to $39,0.33 \mathrm{~kg}$ from d 40 to $42 ;$ HIGH6 $=0.87 \mathrm{~kg}$ from d 0 to $4,1.09 \mathrm{~kg}$ from d 5 to $35,0.54 \mathrm{~kg}$ from d 36 to 42 ; HIGH8 $=0.87 \mathrm{~kg}$ from d 0 to $4,1.09 \mathrm{~kg}$ from d 5 to $45,0.54 \mathrm{~kg}$ from d 46 to $53 ;$ GRAD $8=0.87 \mathrm{~kg}$ for $4 \mathrm{~d}, 1.09 \mathrm{~kg}$ from d 5 to $39,0.87 \mathrm{~kg}$ from d 40 to $43,0.66 \mathrm{~kg}$ from d 44 to $47,0.44 \mathrm{~kg}$ from d 48 to $50,0.22 \mathrm{~kg}$ from d 51 to 53 .

${ }^{2}$ Preplanned contrasts as follows: A = MOD6 vs. (HIGH6 + HIGH8 + GRAD8) 3 ; B = HIGH6 vs. HIGH8; C = HIGH8 vs. GRAD8.

${ }^{3} 1$ to 5 point scale (modified from Wildman et al., 1982).

${ }^{4}$ Total BW gain/(MR + starter intake). 


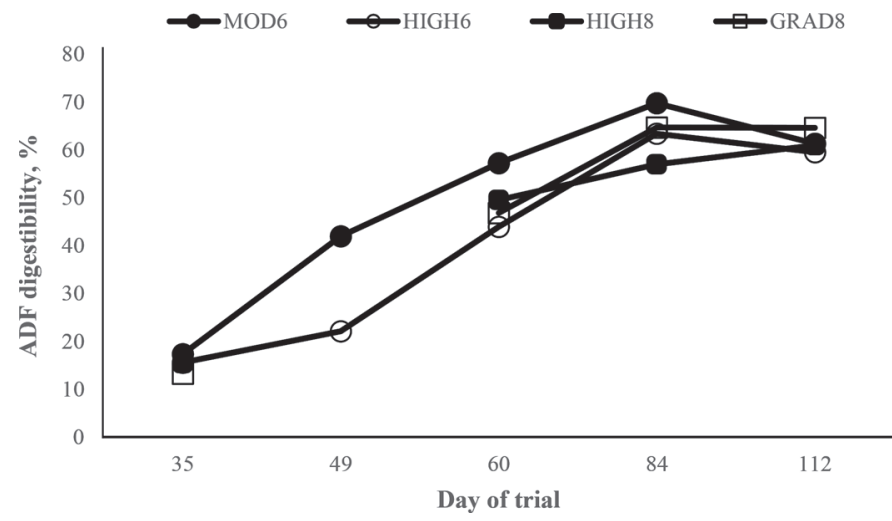

Figure 3. Digestibility of ADF during the nursery and grower trials for calves fed 4 milk replacer programs. Digestibility increased with day during the nursery $(P<0.01)$. MOD6 was greater than others at $\mathrm{d}$ 49,60 , and $84(P<0.05)$; GRAD $8>$ HIGH8 at d $84(P<0.05)$; SEM $=5 \%$ on $\mathrm{d} 35$ and $\leq 3 \%$ on other days. Feeding programs were MOD6 $=0.66 \mathrm{~kg}$ of milk replacer DM from d 0 to $39,0.33 \mathrm{~kg}$ from d 40 to 42 ; HIGH $6=0.87 \mathrm{~kg}$ from d 0 to $4,1.09 \mathrm{~kg}$ from $\mathrm{d} 5$ to $35,0.54 \mathrm{~kg}$ from d 36 to $42 ; \mathrm{HIGH} 8=0.87 \mathrm{~kg}$ from d 0 to $4,1.09 \mathrm{~kg}$ from d 5 to $45,0.54$ $\mathrm{kg}$ from d 46 to 53 ; GRAD $8=0.87 \mathrm{~kg}$ for $4 \mathrm{~d}, 1.09 \mathrm{~kg}$ from $\mathrm{d} 5$ to 39 , $0.87 \mathrm{~kg}$ from d 40 to $43,0.66 \mathrm{~kg}$ from d 44 to $47,0.44 \mathrm{~kg}$ from d 48 to $50,0.22 \mathrm{~kg}$ from d 51 to 53 .

mates made by Hill et al. (2016a). Increasing MR above the $0.66 \mathrm{~kg}$ (MOD6) resulted in reduced digestibility of NDF and ADF on d 49,60, and 84, similar to estimates by Hill et al. (2016a,b). Increasing MR above the 0.66 $\mathrm{kg}$ (MOD6) resulted in reduced digestibility of DM and OM on d 56 and 80 , similar to estimates by Hill et al. (2016b). These short $(\sim 1 \mathrm{wk})$ and intermediate $(\sim 1$

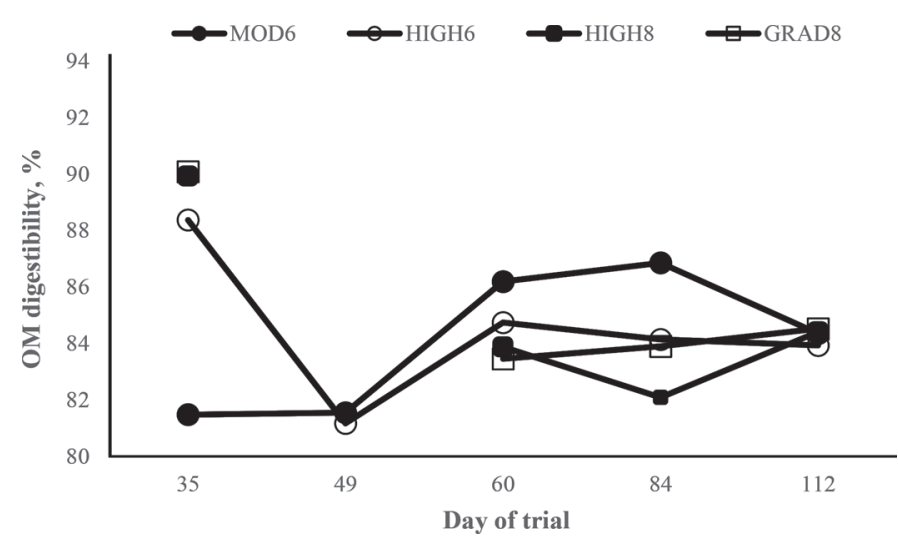

Figure 4. Digestibility of OM during the nursery and grower trials for calves fed 4 milk replacer programs. We observed a treatment by day interaction $(P<0.01)$. MOD6 was less than others on $d 35$ but greater than others on $\mathrm{d} 60$ and $84(P<0.05)$; GRAD8 $>$ HIGH8 on $\mathrm{d}$ $80(P<0.05) ; \mathrm{SEM}=1.8 \%$ on $\mathrm{d} 31$ and $\leq 1.2 \%$ on other days. Feeding programs were MOD6 $=0.66 \mathrm{~kg}$ of milk replacer DM from d 0 to 39 , $0.33 \mathrm{~kg}$ from d 40 to $42 ; \mathrm{HIGH} 6=0.87 \mathrm{~kg}$ from d 0 to $4,1.09 \mathrm{~kg}$ from d 5 to $35,0.54 \mathrm{~kg}$ from d 36 to $42 ;$ HIGH $8=0.87 \mathrm{~kg}$ from d 0 to 4 , $1.09 \mathrm{~kg}$ from d 5 to $45,0.54 \mathrm{~kg}$ from d 46 to 53 ; GRAD $8=0.87 \mathrm{~kg}$ for $4 \mathrm{~d}, 1.09 \mathrm{~kg}$ from d 5 to $39,0.87 \mathrm{~kg}$ from d 40 to $43,0.66 \mathrm{~kg}$ from d 44 to $47,0.44 \mathrm{~kg}$ from d 48 to $50,0.22 \mathrm{~kg}$ from d 51 to 53 .

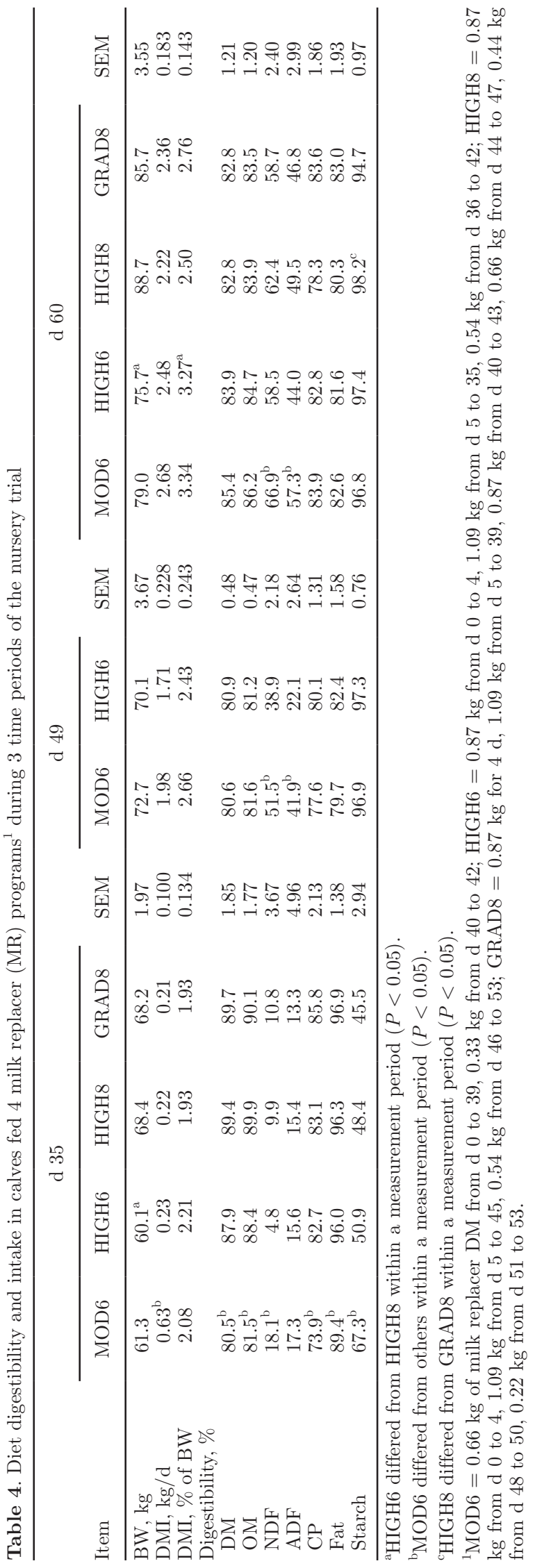


Table 5. Digestibility of nutrients in calves during the grower trial 2 as influenced by the 4 milk replacer programs ${ }^{1}$ fed

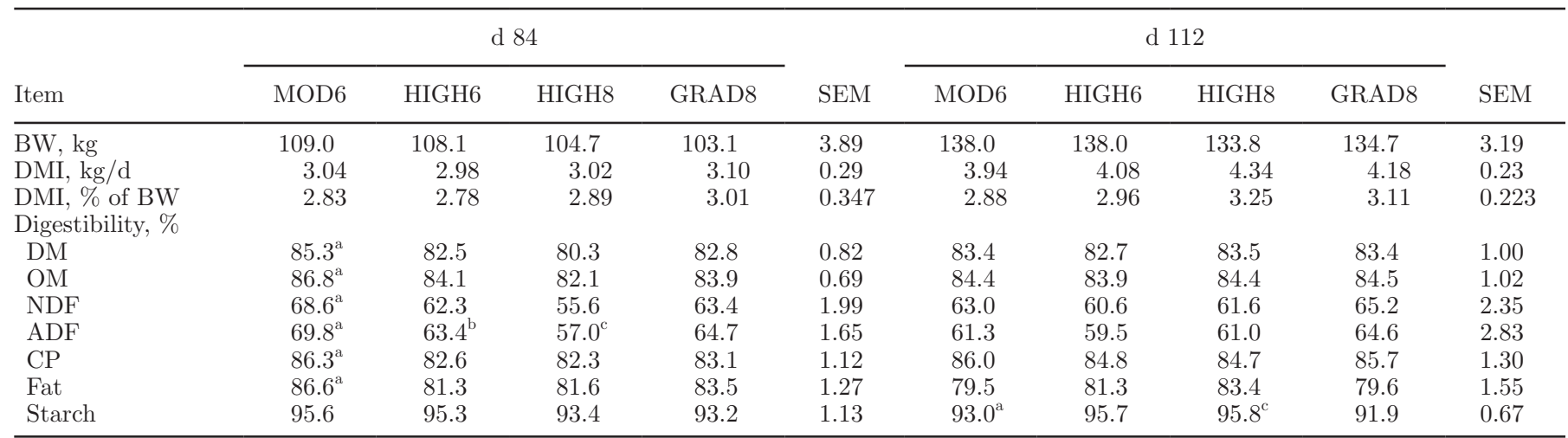

${ }^{\mathrm{a}}$ MOD6 differed from others within a measurement period $(P<0.05)$.

${ }^{\mathrm{b}}$ HIGH6 differed from HIGH8 within a measurement period $(P<0.05)$.

${ }^{\mathrm{c}} \mathrm{HIGH} 8$ differed from GRAD8 within a measurement period $(P<0.05)$.

${ }^{1} \mathrm{MOD} 6=0.66 \mathrm{~kg}$ of milk replacer DM from d 0 to $39,0.33 \mathrm{~kg}$ from d 40 to 42 ; HIGH6 $=0.87 \mathrm{~kg}$ from d 0 to $4,1.09 \mathrm{~kg}$ from d 5 to $35,0.54 \mathrm{~kg}$ from d 36 to $42 ; \mathrm{HIGH} 8=0.87 \mathrm{~kg}$ from d 0 to $4,1.09 \mathrm{~kg}$ from d 5 to $45,0.54 \mathrm{~kg}$ from d 46 to $53 ;$ GRAD $8=0.87 \mathrm{~kg}$ for $4 \mathrm{~d}, 1.09 \mathrm{~kg}$ from d 5 to $39,0.87 \mathrm{~kg}$ from d 40 to $43,0.66 \mathrm{~kg}$ from d 44 to $47,0.44 \mathrm{~kg}$ from d 48 to $50,0.22 \mathrm{~kg}$ from d 51 to 53 .

mo) reductions in digestibility postweaning from feeding more than $0.66 \mathrm{~kg}$ of DM from MR can explain much of the reduction in postweaning growth. Reduced fiber digestion in the preweaning period from feeding higher rates of MR also explains reductions in growth around and immediately postweaning and may be evident in the reduced rate of hip width change observed between wk 6 and 8 (Figure 6 ). Whereas most measurements of digestibility at d 112 did not differ, including $\mathrm{DM}$ and $\mathrm{OM}$ digestibility, starch digestibility was less for MOD6 versus others. This is difficult to explain and illogical, as the diets were high in starch and DM and OM digestibility were not different among treatments. However, the numerical difference in starch digestibility

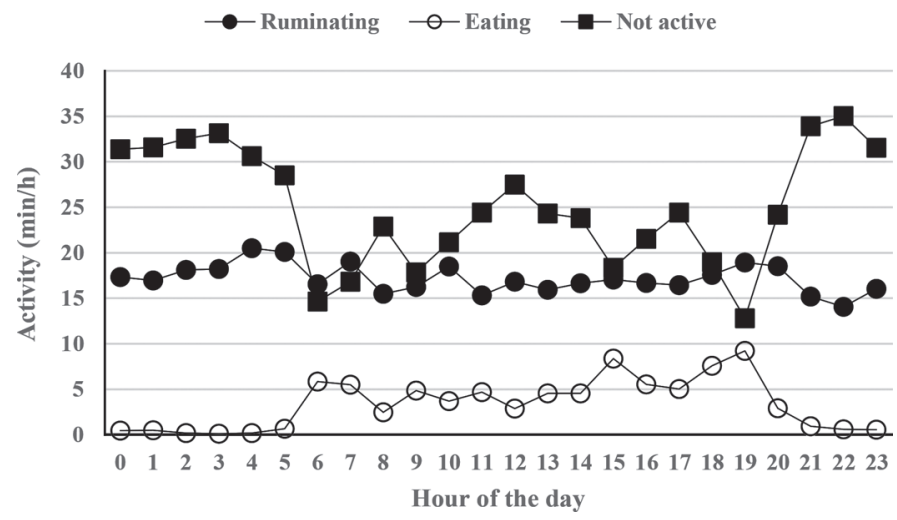

Figure 5. Ruminating, eating, and not active minutes per hour between d 31 and 56 for calves fed the 4 milk replacers programs. We found no differences among the programs. Data are means of 4 treatments. Milk replacer was fed at 0600 and $1530 \mathrm{~h}$. Overall SEM were $0.7 \mathrm{~min} / \mathrm{h}$ for eating, $1.2 \mathrm{~min} / \mathrm{h}$ for eating (milk replacer plus starter), and $1.3 \mathrm{~min} / \mathrm{h}$ for not active. was small (93.0 compared with $94.5 \%$ for MOD6 vs. others) and may be related to analytical error or differences in DMI not captured using average pen intakes.

Calf $\mathrm{ADG} / \mathrm{ME}$ intake and $\mathrm{ADG} / \mathrm{CP}$ intake was not different among treatments from 0 to $56 \mathrm{~d}$; these find-

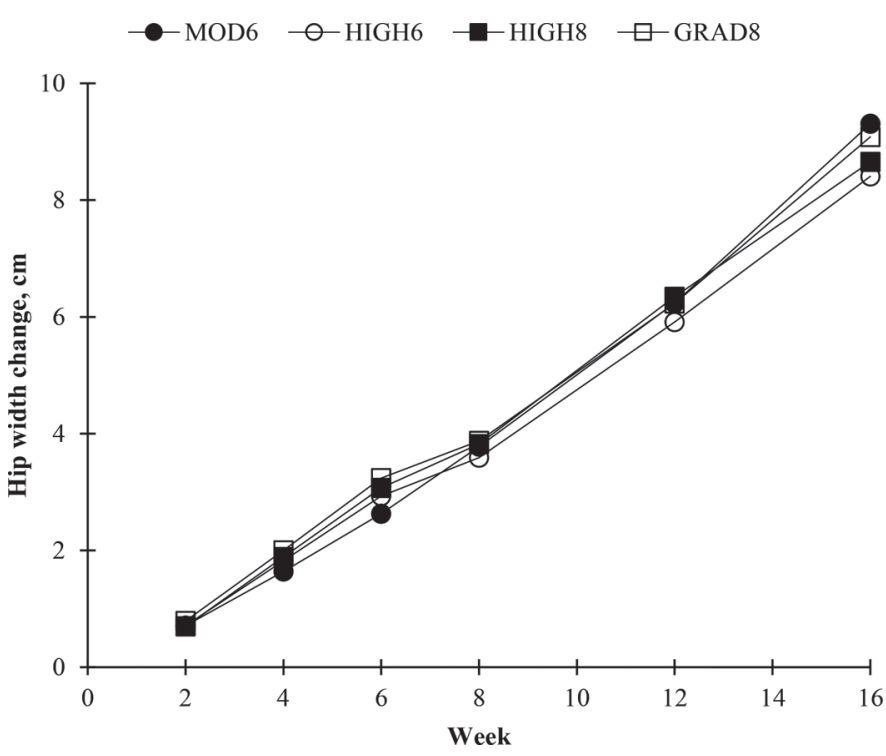

Figure 6. Hip width change during nursery $(0-8 \mathrm{wk})$ and grower trials $(8-16 \mathrm{wk})$ for calves fed 4 milk replacer programs. Change increased with day $(P<0.01)$ and we found a treatment $\times$ day interaction $(P<0.01)$. MOD6 was less than others at wk $4(P<0.05)$. Overall SEM $\leq 0.2 \mathrm{~cm}$. Feeding programs were MOD6 $=0.66 \mathrm{~kg}$ of milk replacer DM from d 0 to $39,0.33 \mathrm{~kg}$ from d 40 to $42 ; \mathrm{HIGH} 6=$ $0.87 \mathrm{~kg}$ from d 0 to $4,1.09 \mathrm{~kg}$ from d 5 to $35,0.54 \mathrm{~kg}$ from d 36 to 42 ; HIGH8 $=0.87 \mathrm{~kg}$ from d 0 to $4,1.09 \mathrm{~kg}$ from d 5 to $45,0.54 \mathrm{~kg}$ from d 46 to 53; GRAD $8=0.87 \mathrm{~kg}$ for $4 \mathrm{~d}, 1.09 \mathrm{~kg}$ from d 5 to $39,0.87 \mathrm{~kg}$ from d 40 to $43,0.66 \mathrm{~kg}$ from d 44 to $47,0.44 \mathrm{~kg}$ from d 48 to $50,0.22$ $\mathrm{kg}$ from d 51 to 53 . 
ings are similar to previous results (Hill et al., 2016a,b; Rosenberger et al., 2017). Similar efficiency of ME and $\mathrm{CP}$ intake use is concerning because MR digestibility, in addition to the costs, is high relative to calf starter. Labor cost to feed MR is also high and high feeding rate programs require more complicated step-up and step-down protocols, which challenge correct implementation on many farms. Nutrient efficiencies should be greater when MR is fed at a high rate and is a greater percentage of the diet. Although diet digestibility (starch, ADF, and NDF being greater for MOD6 vs. others) may partially explain similar nutrient efficiencies, starter represents less than $50 \%$ of the diet preweaning depending on MR feeding rate. Another explanation may be that metabolic issues play role. For example, Bach et al. (2013) reported that inefficient growth may be due to insulin insensitivity caused by feeding large amounts of MR. This research group also found that frequency of MR feeding play a role in inefficiency of growth (Bach et al., 2013).

Feeding the high rate of MR longer (HIGH8 vs. HIGH6) did not improve growth to $112 \mathrm{~d}$ as in other studies to 10 (Eckert et al., 2015) and 13 wk (Meale et al., 2015) of age. Eckert et al. (2015) reported a 9-kg advantage in BW at 70 and $90 \mathrm{~d}$ of age and an 11-kg advantage in BW at $150 \mathrm{~d}$ of age for calves weaned at 8 compared with 6 wk of age. Reasons for disagreement in the literature are unclear, though dry feed offered in the current trial differed in particle size and forage inclusion before weaning, as calves in Eckert et al. (2015) and Meale et al. (2015) were offered completely pelleted starters with lower reported ME content and free-choice access to chopped straw. As mentioned earlier, BW gain may be influenced by GIT fill around the time of weaning, and Khan et al. (2011) observed calves fed up to $8 \mathrm{~L} / \mathrm{d}$ of pasteurized waste milk and offered textured calf starter with chopped grass hay consumed significantly more starter from 6 to $10 \mathrm{wk}$ of age compared with calves not given hay. Calf BW at 10 wk of age was similar between treatments, but empty BW at slaughter was numerically $5 \mathrm{~kg}$ lighter for calves fed starter with chopped grass hay (93.6 vs. $98.6 \mathrm{~kg}$; Khan et al., 2011). Whereas forage was not offered preweaning and immediately postweaning in the current study, it is plausible that GIT fill could inflate BW for calves that increase starter intake postweaning to compensate for MR removal. The gradual weaning program in the current trials (GRAD8) and a gradual weaning program examined by Hill et al. (2016b) showed some promise to improve growth to $112 \mathrm{~d}$ and digestibility postweaning. However, GRAD8 and the gradual weaning program used in Hill et al. (2016b) did not result in large improvements over MOD6.
Other differences could be from the inclusion of specific AA and fatty acids in the current MR and starter compared with diets fed by Eckert et al. (2015) and Meale et al. (2015). Proper inclusion of these nutrients have improved ADG, hip width change, and feed efficiency in calves by $>10 \%$ from 0 to 4 mo of age. Additionally, improvements in digestibility have been reported with the use of specific fatty acids, helping to alleviate some the reductions in growth reported when feeding MR at rates $>0.66 \mathrm{~kg}$ of DM daily (Hill et al., 2016a).

We noted few differences in eating, ruminating, and inactive duration. Over all treatments, calves were more active. After weaning was initiated (MR was removed at the p.m. feeding), HIGH6 and HIGH8 calves increased their activity more than MOD6 and GRAD8 calves. Differences in activity for HIGH6 and HIGH8 compared with MOD6 were likely observed because MOD6 calves were more acclimated to eating starter, whereas compared with GRAD8, HIGH6, and HIGH8 likely relied more on their high-MR intake to be satiated and more abrupt weaning caused HIGH6 and HIGH8 to increase activity. In other research with calves on computerized automatic feeders, calves fed less milk had more unrewarded visits and more time with unrewarded visits than calves fed more milk (Jensen, 2006); these visits declined over the weeks before weaning. Jensen associated unrewarded visits with hunger and the decline leading up to weaning with the calves satisfying their hunger with consumption of more starter. Similarly, Rosenberger et al. (2017) found more unrewarded visits to computerized automatic feeders when preweaned calves were allotted $6 \mathrm{~L}$ of reconstituted MR than with higher allotments $(8,10$, and 12 L). Their observed relationship of unrewarded visits to MR allotment was linear (more visits with less MR allotted) during the weaning week when MR was reduced and free-choice starter intake increased rapidly. Calves on the 6 - $\mathrm{L}$ allotment averaged $0.3 \mathrm{~kg}$ of starter $\mathrm{DMI} / \mathrm{d}$ in the preweaning period before allotment reduction at 6 wk. Comparatively, MR and starter intake of our MOD6 treatment was similar during this period to that reported by Rosenberger et al. (2017). Calves fed greater MR rates than MOD6 appeared to have slightly greater starter intakes preweaning than the 8-, 10-, and 12-L allotments in Rosenberger et al. (2017), where calves consumed 0 to $0.1 \mathrm{~kg} / \mathrm{d}$ starter intake preweaning. Starter intakes such as those reported for calves fed 8, 10 and $12 \mathrm{~L}$ of MR or our high-MR treatments would have less-developed digestive systems to digest starters and be prepared for weaning. Coarse textured starters high in starch, as fed in the current study, might provide advantages to stimulate starter intake and ru- 
men development (Porter et al., 2007; Suarez-Mena et al., 2016) through increased particle size. Rosenberger et al., (2017) did not provide a description of starter physical form, but did contain similar concentrations of starch and NDF and was fed via an automated feeder.

In hand-fed calves, the bout frequency and milk sucking time per bout (including milk feeding and nonnutritive sucking) to the nipple-feeder did not differ between ad libitum- and restricted-fed calves (MillerCushon et al., 2013). When weaned, the calves previously fed restricted milk had greater rates of starter intake and meal amounts than calves fed milk ad libitum. These behaviors suggested that calves fed restricted milk were better prepared to compete for and consume starter postweaning. However, weaned eating behaviors and activities became similar between restricted and ad libitum fed calves with time.

Nonetheless, the variation among calves in eating, ruminating, and activity as measured in our trial was possibly a reason why we found no differences in these behaviors among treatments. Eating and ruminating behavior in older heifers has been reported to be large, and Deswysen et al. (1993) discussed the results of other research reporting the large animal to animal variation in eating and ruminating activities. In our nursery trial, calves ruminated 15 to 20 min each hour of the day. They spent $<1$ min eating overnight between 2100 and $0500 \mathrm{~h}$ and $\leq 9 \mathrm{~min} / \mathrm{h}$ eating the other hour of the day. To our knowledge, extensive $(24 \mathrm{~h} / \mathrm{d})$ and continuous (3 wk) measurements of calf ruminating and eating behaviors does not exist in the literature. Research such as this may become easier with electronic, mobile, and wireless systems and help us to understand how feeding and management programs affect digestive development and behaviors in neonatal calves.

\section{CONCLUSIONS}

Feeding $0.66 \mathrm{~kg}$ of DM/d from a $25 \% \mathrm{CP}, 17 \%$ fat $\mathrm{MR}$ and weaning at $6 \mathrm{wk}$ of age with a 3 -d transition to complete weaning to a high-starch, textured starter with whole grains resulted in similar BW and structural growth through 4 mo of age as MR programs feeding up to $1.1 \mathrm{~kg}$ of $\mathrm{DM} / \mathrm{d}$ and weaning at 6 or $8 \mathrm{wk}$ of age. A gradual weaning over $2 \mathrm{wk}$ and weaning at 8 wk did not improve growth rates to any large degree. Greater total-tract digestion of starch preweaning and greater digestion of $\mathrm{ADF}$ and $\mathrm{NDF}$ preweaning and to approximately 1 mo postweaning contributed to the reason MR was as effective to support growth to 4 mo of age when feeding $0.66 \mathrm{~kg}$ of DM as programs feeding 15.1 to $28.6 \mathrm{~kg}$ more MR/calf. The moderate MR program also appeared to better prepare calves for weaning. Whereas feeding up to $1.1 \mathrm{~kg}$ of $\mathrm{DM} / \mathrm{d}$ of
MR supported more BW and BCS gain preweaning, it did not result in more structural growth compared with feeding $0.66 \mathrm{~kg}$ of $\mathrm{DM} / \mathrm{d}$ from MR and weaning at 6,8 , and 16 wk. The current growth and digestibility measurements for the moderate and high treatments were in agreement with several other measurements in the literature.

\section{ACKNOWLEDGMENTS}

This research was completely funded by Provimi.

\section{REFERENCES}

AOAC International. 2000. Official Methods of Analysis. Vol. I. 17th ed. AOAC International, Arlington, VA.

Bach, A., L. Domingo, C. Montoro, and M. Terre. 2013. Short communication: Insulin responsiveness is affected by the level of milk replacer offered to young calves. J. Dairy Sci. 96:4634-4637.

Bouchard, R., G. J. Brisson, and J. P. Julien. 1973. Nutritive value of bacterial sludge and whey powders for protein in calf milk replacers and on chromic oxide as indicator of digestibility. J. Dairy Sci. $56: 1445-1449$

Cowles, K. E., R. A. White, N. L. Whitehouse, and P. S. Erickson. 2006. Growth characteristics of calves fed an intensified milk replacer regime with additional lactoferrin. J. Dairy Sci. 89:48354845 .

Deswysen, A. G., P. Dutilleul, J. P. Godfrin, and W. C. Ellis. 1993. Nycterohemeral eating and ruminating patterns in heifers fed grass or corn silage: analysis by finite fourier transform. J. Anim. Sci. 71:2739-2747.

Dubois, M., K. A. Gilles, J. K. Hamilton, P. A. Rebers, and F. Smith. 1956. Colorimetric method for determination of sugars and related substances. Anal. Chem. 28:350-356.

Eckert, E., H. E. Brown, K. E. Leslie, T. J. DeVries, and M. A. Steele. 2015. Weaning age affects growth, feed intake, gastrointestinal development, and behavior in Holstein calves fed an elevated plane of nutrition during the preweaning stage. J. Dairy Sci. 98:6315-6326.

FASS. 2010. Guide for the Care and Use of Agricultural Animals in Research and Teaching. 3rd ed. Federation of Animal Science Societies, Savoy, IL.

Hall, M. B. 2009. Analysis of starch, including maltooligosaccharides, in animal feeds: A comparison of methods and a method recommended for AOAC collaborative study. J. AOAC Int. 92:42-49.

Hill, T. M., J. M. Aldrich, R. L. Schlotterbeck, and H. G. Bateman II. 2007. Effects of the feeding rate of high protein calf milk replacers. Prof. Anim. Sci. 23:649-655.

Hill, T. M., H. G. Bateman II, J. M. Aldrich, J. M. Quigley, and R. L. Schlotterbeck. 2013. Evaluation of acidified, ad libitum milk replacer programs for dairy calves. J. Dairy Sci. 96:3153-3162.

Hill, T. M., H. G. Bateman II, J. M. Aldrich, and R. L. Schlotterbeck. 2010. Effect of milk replacer program on digestion of nutrients in dairy calves. J. Dairy Sci. 93:1105-1115.

Hill, T. M., H. G. Bateman II, J. M. Aldrich, and R. L. Schlotterbeck. 2012. Methods of reducing milk replacer to prepare dairy calves for weaning when large amounts of milk replacer have been fed. Prof. Anim. Sci. 28:332-337.

Hill, T. M., H. G. Bateman II, J. M. Aldrich, R. L. Schlotterbeck, and K. G. Tanan. 2008. Optimal concentrations of lysine, methionine, and threonine in milk replacers for calves less than five weeks of age. J. Dairy Sci. 91:2433-2442.

Hill, T. M., J. D. Quigley, H. G. Bateman II, J. M. Aldrich, and R. L. Schlotterbeck. 2016a. Effect of milk replacer feeding rate and functional fatty acids on dairy calf performance and digestion of nutrients J. Dairy Sci. J. Dairy Sci. 99:6352-6361.

Hill, T. M., J. D. Quigley, H. G. Bateman II, F. X. Suarez-Mena, T. S. Dennis, and R. L. Schlotterbeck. 2016b. Effect of milk replacer 
program on calf performance and digestion of nutrients in dairy calves to 4 months of age. J. Dairy Sci. 99:8103-8110.

Hill, T. M., F. X. Suarez-Mena, W. Hu, T. S. Dennis, R. L. Schlotterbeck, and L. E. Hulbert. 2017. Technical note: Evaluation of an ear-attached movement sensor to record rumination, eating, and activity behaviors in one-month old calves. Prof. Anim. Sci. In Press.

Hill, T. M., M. J. VandeHaar, L. M. Sordillo, D. R. Catherman, H. G. Bateman II, and R. L. Schlotterbeck. 2011. Fatty acid intake alters growth and immunity of milk-fed calves. J. Dairy Sci. 94:39363948.

Jensen, M. B. 2006. Computer-controlled milk feeding of group-housed calves: The effect of milk allowance and weaning type. J. Dairy Sci. 89:201-206.

Kertz, A. F., and H. Chester-Jones. 2004. Invited review: Guidelines for measuring and reporting calf and heifer experimental data. J. Dairy Sci. 87:3577-3580.

Khan, M. A., D. M. Weary, and M. A. von Keyserlingk. 2011. Hay intake improves performance and rumen development of calves fed higher quantities of milk. J. Dairy Sci. 94:3547-3553.

Meale, S. J., L. N. Leal, J. Martín-Tereso, and M. A. Steele. 2015. Delayed weaning of Holstein bull calves fed an elevated plane of nutrition impacts feed intake, growth and potential markers of gastrointestinal development. Anim. Feed Sci. Tech. 209:268-273.

Miller-Cushon, E. K., R. Bergeron, K. E. Leslie, and T. J. DeVries. 2013. Effect of milk feeding level on development of feeding behavior in dairy calves. J. Dairy Sci. 96:551-564.

NRC. 2001. Nutrient Requirements of Dairy Cattle. 7th rev. ed. Natl. Acad. Sci., Washington, DC.

Nocek, J. E., and D. G. Braund. 1986. Performance, health, and postweaning growth on calves fed cold, acidified milk replacer ad libitum. J. Dairy Sci. 69:1877-1883.

Osorio, J. S., R. L. Wallace, D. J. Tomlinson, T. J. Earleywine, M. T. Socha, and J. K. Drackley. 2012. Effects of source of trace minerals and plane of nutrition on growth and health of transported neonatal dairy calves. J. Dairy Sci. 95:5831-5844.
Porter, J. C., R. G. Warner, and A. F. Kertz. 2007. Effect of fiber level and physical form of starter on growth and development of dairy calves fed no forage. Prof. Anim. Sci. 23:395-400.

Robertson, J. B., and P. J. Van Soest. 1981. The Detergent System of Analysis and its Application to Human Foods. Cornell University, Ithaca, NY.

Rosenberger, K., J. H. C. Costa, H. W. Neave, M. A. G. von Keyserlingk, and D. M. Weary. 2017. The effect of milk allowance on behavior and weight gains in dairy calves. J. Dairy Sci. 100:504-512.

Suarez-Mena, F. X., T. M. Hill, C. M. Jones, and A. J. Heinrichs. 2016. Review: Effect of forage provision on feed intake in dairy calves. Prof. Anim. Sci. 32:383-388.

Sweeney, B. C., J. Rushen, D. M. Weary, and A. M. de Passillé. 2010. Duration of weaning, starter intake, and weight gain of dairy calves fed large amounts of milk. J. Dairy Sci. 93:148-152.

Terre, M., M. Devant, and A. Bach. 2007a. Effect of level of milk replacer fed to Holstein calves on performance during the preweaning period and starter digestibility at weaning. Livest. Sci. 110:82-88

Terre, M., M. Devant, and A. Bach. 2007b. Performance and nitrogen metabolism of calves fed conventionally or following an enhancedgrowth feeding program during the preweaning period. Livest. Sci. 105:109-119.

Van Keulen, J. V., and B. A. Young. 1977. Evaluation of acid insoluble ash as a natural marker in ruminant digestibility studies. J. Anim. Sci. 44:282-287.

Van Soest, P. J., J. B. Robertson, and B. A. Lewis. 1991. Methods for dietary fiber, neutral detergent fiber, non-starch polysaccharides in relation to animal nutrition. Symposium: carbohydrate methodology, metabolism and nutritional implications in dairy cattle. J. Dairy Sci. 74:3583-3597.

Wildman, E. E., G. M. Jones, P. E. Wagner, R. L. Boman, H. F. Trout Jr., and T. N. Lesch. 1982. A dairy cow body condition scoring system and its relationship to selected production characteristics. J. Dairy Sci. 65:495-501. 